\title{
Effects of Stage of Harvest and Post-harvest Ripening of Fruits on Seed Yield and Quality in Cucumber Grown under Open Field and Protected Environments
}

\author{
Nakul Gupta ${ }^{1 *}$, Sunil Kumar ${ }^{1}$, S. K. Jain ${ }^{1}$, B. S. Tomar ${ }^{1}$, \\ Jogendra Singh $^{1}$ and Vishwanath Sharma ${ }^{2}$ \\ ${ }^{1}$ ICAR-Indian Agricultural Research Institute, New Delhi, India \\ ${ }^{2}$ Rainforest Research Institute, Jorhat, Assam, India \\ *Corresponding author
}

\section{A B S T R A C T}

\section{Keywords}

Cucumber, Seed development, Postharvest ripening, Environment, Seed yield and Quality, seed composition, ROS, Antioxidants

\section{Article Info}

Accepted: 12 December 2020 Available Online: 10 January 2021
Among the various stages of fruit harvest (35, 40, 45 DFP under open field (E1); and 45, 50, 55 DFP under protected (E2) environments, in combination with post-harvest ripening (PHR) periods (0, 10, 20 and 30-days);treatment F2P4 (40 DFP+30-days PHR), followed by F3P3 (45 DFP+20-days PHR) under open field, whereas, treatment C2P4 (50 DFP+30days PHR), followed by C3P3 (55 DFP+20-days PHR) under protected environment, were superior in optimizing both seed yield and quality in two cucumber varieties (Pusa Barkha and Pusa Uday), during 2019-20, at ICAR-IARI, New Delhi. The seed yield attributes (i.e total filled seed and 1000-seed weight) and seed quality attributes (germination and vigour) were higher under protected environment. Maximum seed fresh \& dry weights, and minimum seed moisture content, EC, TSS and TSP (from seed leachates) were registered with treatments $\mathrm{F} 3 \mathrm{P} 3$ under E1, and $\mathrm{C} 3 \mathrm{P} 3$ under E2. Of the seed composition, total soluble proteins, starch and oil contents (in seed) increased with the progression of seed maturation and PHR period (0 to 30-days), whereas total soluble sugars (in seed) significantly reduced, may be due to its conversion into starch. Reduced $\operatorname{ROS}\left(\mathrm{O}_{2}{ }^{\circ-}\right.$ and $\mathrm{H}_{2} \mathrm{O}_{2}$ ) in PHR seeds (from all stages of seed development), may be due to reduction in seed moisture, which imposes a lower potential threat to seed, consequently reduced antioxidants(SOD, CAT and POX); indicative of physical and physiological soundness of seeds.

\section{Introduction}

Among cucumber fruits, the peel and seeds are the most nutrient-rich, contain phytonutrients, fibres and antioxidants. Besides, seeds contain oil, helpful for brain development and smooth body, is also being used in ayurvedic preparations. Seed production in cucumber has the problem of higher number of under developed seed with reduced quality. The yield and quality of seed produced depends on various factors viz soil, climate, cultural practices and more importantly, on the stage of seed harvest 
toensure maximum performance (Delouche, 1980).In many vegetable species, early harvest may lead to higher number of immature and underdeveloped seeds, whereas delayed harvest may result in fast ageing or vivipary, as seed moisture remain high (Bradford, 2004). Therefore, optimizing the appropriate harvest time/stage for seeds is important especially in fleshy fruits. Harrington (1972) demonstrated that seed attain maximal vigour and potential germinability at physiological maturity, where seed filling ends. However, determination of optimum harvesting stage is difficult in species like cucumber, which have indeterminate growth and an extended flowering period (Katinas et al., 2016). The association of time or stage of seed harvest with maximal quality (seed and fruit attributes) had shown great variation among crops, cultivars and locations. Some workers have identified some markers for stage of seed harvest with maximal quality viz maximum seed dry matter accumulation, moisture content, fruit colour, chlorophyll content and days from anthesis/pollination, etc (Jing et al., 2000).

Cucumber seeds remain impregnated in fruit pulp throughout its life cycle (Gupta et al., 2021a). Therefore, In fleshy fruit/vegetables like cucumber, pumpkin, melons etc, the postharvest ripening of fruit is very significant to maximize seed yield and quality, as the seeds continue to develop and mature in the fruit even after harvest until the seed extraction (Alen and Eser, 2008; Silva et al., 2017).PHR of fruits/vegetables, in many crops, increased seed viability, vigour, field emergence and allow immature seeds to achieve the maturity (Alan and Eser, 2008; Passam et al., 2010; Kalyanrao et al., 2014; Kortse et al., 2017). Seed PHR may be done either within the fruit before seed extraction or dry storage of extracted seeds.
The physio-biochemical changes such as accumulation of food reserves along with the ROS and antioxidants in seed during PHR were not known. Thus, the present study was aimed to identify the optimum harvest stage in combination with post-harvest ripening period to achieve maximal seed yield and quality with chosen two cucumber varieties under two environments (open field and protected) in reference to physical, physiological and biochemical changes in developing seed.

\section{Materials and Methods}

\section{Experimental site and material}

The field experiments were carried out under two environments, viz E1: open field environment (Division of Vegetable Science), and E2: protected environment (Centre for Protection Cultivation Technology (CPCT)), under irrigated conditions, during 2019-20 at ICAR-Indian Agricultural Research Institute, New Delhi (IARI). The seeds of two chosen cucumber varieties (PusaBarkha and Pusa Uday) during both the seasons, under E1 were directly planted on the raised beds and floodirrigated, whereas under E2, the vines were trailed and drip-irrigated. To ensure the pollination, the flowers were hand pollinated (7-10am) and tagged. 2-3 fruits per plant were retained. Fruits from these tagged flowers, were harvested on 35, 40 and 45 DFP under open field condition, whereas on 45, 50 and 55 DFP under protected environment. Fruits thus harvested, from both growing environments, were stored for post-harvest ripening periods $(0,10,20$ and 30 -days), prior to seed extraction. The treatments details are given (Table 1).

Seeds from different treatment combinations were used in three replicates. Seeds from five fruits were extracted immediately (at the start of PHR), whereas remaining 15 fruits were 
stored at lab ambient temperature for PHR; seeds were extracted accordingly, for further use.

\section{Seed attributes}

Using three replicates, viz total number of seeds per fruit; total number of filled/unfilled seeds per fruit \& its \%age, were determined from 5 fruits each in each replicate, and counted; the mean values were computed; 1000-seed weight was calculated following ISTA rules (Anon, 2019).Seed dimensions, from 25 seeds in each, were measured using a digital Vernier Caliper (RS PRO 150mm Digital Caliper, India). Seed fresh and dry weights:from 10 seeds per replicate, using a precision balance were computed.Other seed quality attributes viz seed germination; 50 seeds per replicate \& seed moisture content: $1-2 \mathrm{~g}$ seeds following ISTA rules (Anon, 2019); seed vigour indices; from 10 normal seedlings per replicate, following Abdul-baki and Anderson (1973) were computed.

Among physiological and biochemical assays, electrical conductance from seed leachates: 10 seeds/30ml MQ water, in each replicate following Pandita and Nagarajan (2006); total soluble sugars (TSS) following Dubois et al (1956); and total soluble proteins following Bradford (1976); total starch content using Anthrone method (Hodge and Hofreiter, 1962); seed oil using Soxhlet extractor following (AOAC, 1990); ROS (superoxide anion $\left(\mathrm{O}_{2}{ }^{-}\right)$following Chaithanya and Naithani (1994); hydrogen peroxide $\left(\mathrm{H}_{2} \mathrm{O}_{2}\right)$ following Mukherjee and Choudhari (1983); and antioxidants viz SOD following Dhindsa et al., (1981); CAT following Aebi et al., (1984), whereas POX following Rao et al.,(1996) were estimated and computed.

The experiment was conducted in a complete randomized block design using three replicates, following a bifactorial scheme $(6 \mathrm{x}$
2 under E1 and 9 x 2 under E2, respectively) and subjected to analysis of variance (ANOVA). The data as percentage were transformed to arc sin values prior to statistical analysis. Statistical analyses were carried using WASP 2.0 and Microsoft Excel 2019.

\section{Results and Discussion}

\section{Fruit and seed attributes}

Fruit developmental characters viz weight, length, width, cavity size and flesh thickness showed significant variations at various stages of fruit harvest under both the environments, whereas during PHR all fruit development attributes, except fruit weight were consistent. Irrespective of growing environments, stages of fruit harvest in combination with PHR period significantly affected the seed development and yield attributes.

The mean values of two varieties from two seasons, depicted significantly maximum number of filled seeds: under E1, from treatment F2P4 [285.5 (79.54\%)]followed by F3P3 [284.0 (78.83\%)]; and under E2, with treatment C2P4 [293.0 (79.88\%)] followed by C3P3 [292.0 (79.22\%)]; whereas the minimum number were recorded with F1P1 [231.8 (69.74\%)]; and C1P1 [240.0 (70.43\%)] under E1 and E2, respectively (Fig 1). Irrespective of varieties, seasons and environments, the total number of seeds per fruit remains constant with different stages of fruit harvest and PHR period (Fig 1). Irrespective of varieties and seasons, maximum number of unfilled seed was recorded with F1P1 [100.5 (29.54\%)] and C1P1 [100.8 (29.17\%)]. Maximal 1000-seed weight were recorded in treatment $\mathrm{F} 3 \mathrm{P} 3$ (24.54g) followed by F2P4 (24.46g) under $\mathrm{E} 1$, and in treatment $\mathrm{C} 3 \mathrm{P} 4(24.16 \mathrm{~g})$ followed by C2P4 (24.78g) under E2, respectively (Fig $1)$. 
Maximal seed length and breadth were recorded in treatment $\mathrm{F} 3 \mathrm{P} 3 \quad(10.24$ \& $3.66 \mathrm{~mm})$ followed by F2P4 $(9.86 \& 3.63 \mathrm{~mm})$ under E1, and in treatment C3P4 (10.76 \& $3.83 \mathrm{~mm})$ followed by C2P4 (10.31 \& $3.78 \mathrm{~mm}$ ) under E2, respectively (Fig 2).

\section{Seed quality attributes}

Irrespective of varieties and seasons, significant differences were registered among different stages of fruit harvest and PHR period for seed quality parameters viz seed germination, seedling growth, seedling dry weight, and seed vigour indices under both growing environments. Maximum seed germination was registered with treatment F2P4 (80.84\%) followed by F3P3 (79.12\%) under E1, whereas with C2P4 (82.63\%) followed by C3P3 (81.46\%) under E2 (Fig 3).

Likewise, maximum seedling growth $(17.53 \mathrm{~cm})$, seedling dry weight $(0.132 \mathrm{~g} 10$ seedling $\left.^{-1}\right)$, seed vigour index-I (1418.5) and seed vigour index-II (10.57) were recorded with treatment F2P4 under E1; and maximum seedling growth $(19.19 \mathrm{~cm})$, seedling dry weight $\left(0.139 \mathrm{~g} 10\right.$ seedling $\left.^{-1}\right)$, seed vigour index-I (1585.0) and seed vigour index-II (11.36) were recorded with treatment $\mathrm{C} 2 \mathrm{P} 4$ under E2. The minimum mean values were recorded with F1P1 \& C1P1 for seed germination (50.09 \& 64.25\%), seedling length $(13.32 \& 16.07 \mathrm{~cm})$, seedling dry weight $\left(0.089 \& 0.114 \mathrm{~g} 10\right.$ seedling $\left.^{-1}\right)$, seed vigour index-I (667.0 \& 1032.5) and seed vigour index-II (4.44 \& 7.32), respectively (Fig 3).

Irrespective of varieties and seasons, moisture content, fresh \& dry weights of seeds showed significant differences among the treatments. Highest seed mc were observed with F1P1 (24.10\%) \& C1P1 (23.37\%), whereas, lowest seed mc were recorded with F3P3 (16.55\%) \& C3P3 (17.18\%) under E1 \& E2, respectively (Fig 4). Under E1, the maximum fresh and dry weights of seeds were recorded with F3P3 (24.54 \& $20.47 \mathrm{mg}$ ), followed by F2P4 (24.46 \& 20.07mg), whereas the minimum values with F1P1 (23.14 \& $17.56 \mathrm{mg}$, respectively). Whereas under E2, the maximum fresh and dry weights of seeds were recorded with C3P3 (24.81 \& 20.35mg), followed by C2P4 $\left(24.78 \mathrm{mg}_{\mathrm{fw}}\right)$ \& C3P2 $\left(20.37 \mathrm{mg}_{\mathrm{dw}}\right)$, and the minimum values with C1P1 (23.76 \& $18.20 \mathrm{mg}$ ), respectively (Fig $4)$.

\section{Physiological and biochemical assays}

\section{Electrical conductance (EC) from seed leachates}

Significant differences for electrical conductance were registered among various treatment combinations. Increase in PHR period, in general, significantly reduced the EC value, irrespective of the treatments and environments. The minimal values were registered, under E1, with $\mathrm{F} 3 \mathrm{P} 3(112.8 \mu \mathrm{Scm}$ $\left.{ }^{1} \mathrm{~g}^{-1}\right)$ followed by F2P4 $\left(116.3 \mu \mathrm{Scm}^{-1} \mathrm{~g}^{-1}\right)$; under $\mathrm{E} 2$, with $\mathrm{C} 3 \mathrm{P} 3 \quad\left(130.2 \mu \mathrm{Scm}^{-1} \mathrm{~g}^{-1}\right)$ followed by $\mathrm{C} 2 \mathrm{P} 4 \quad\left(133.8 \mu \mathrm{Scm}^{-1} \mathrm{~g}^{-1}\right)$. Whereas, maximal values for $\mathrm{EC}$ were registered, under E1, with F1P1 $\left(224.7 \mu \mathrm{Scm}^{-}\right.$ $\left.{ }^{1} \mathrm{~g}^{-1}\right)$, and $\mathrm{C} 1 \mathrm{P} 1\left(241.9 \mu \mathrm{Scm}^{-1} \mathrm{~g}^{-1}\right)$ under E2 (Fig 5).

The EC value was positively correlated with an amount of TSS and TSP in seed leachates and vice-versa. TSS \& TSP in seed leachates were minimum with treatment F3P3 $(0.704 \&$ $\left.6.8 \mathrm{mg} \mathrm{g}^{-1}\right)$ followed by F2P4 $(0.710 \& 6.9 \mathrm{mg}$ $\mathrm{g}^{-1}$ ) under E1; and with C3P3 (0.809 \& 6.6mg $\left.\mathrm{g}^{-1}\right)$ followed by C2P4 $\left(0.814 \& 6.6 \mathrm{mg} \mathrm{g}^{-1}\right)$ under E2. Whereas, the maximum TSS \& TSP in seed leachates were recorded with treatment F1P1 (1.119 \&11.5 $\left.\mathrm{mg} \mathrm{g}^{-1}\right)$; and with C1P1 (1.234 \& 10.6mg g $\left.{ }^{-1}\right)$ under E1 \& E2, respectively) (Fig 5). 


\section{Seed composition}

Irrespective of varieties and seasons, the variations for seed composition viz TSS, TSP, total starch and oil contents were significant between two growing environments only. TSS decreased (-1.10 to -1.18 -folds) with increase in PHR duration (0 to 30-days) irrespective of harvesting stages, under E1 \& E2. TSS in developing seed, under E1 (35-45 DFP) significantly decreased (-1.29-folds) (3.443 to $2.675 \mathrm{mg} \mathrm{g}^{-1}{ }_{\mathrm{dw}}$ ), whereas under E2 (45-55 DFP), it decreased (-1.33-folds) (3.998 to $3.008 \mathrm{mg} \mathrm{g}^{-1}{ }_{\mathrm{dw}}$ ) (Fig 6). TSS accumulation registered a strong but a negative correlation with the seed developmental stages and PHR period ( $\mathrm{r}=-0.92$ to $-0.99, \mathrm{p}<0.05$ ).TSP showed an increasing trend with increasing PHR period (0 to 30-days) with all the treatments, except $\mathrm{F} 3 \mathrm{P} 4$ and $\mathrm{C} 3 \mathrm{P} 4$. TSP accumulation in developing seed with PHR (mean values) under E1 (35-45 DFP), increased 1.19-folds ( 128.3 to $161.7 \mathrm{mg} \mathrm{g}^{-1}{ }_{\mathrm{dw}}$ ), whereas under E2 (45-55 DFP) it increased 1.33 -folds from (138.51 to $197.43 \mathrm{mg} \mathrm{g}_{\mathrm{dw}}^{-1}$ ) (Fig 6). Total starch contents in seed depicted a reverse trend of sugar accumulation, which upsurge constantly until maturity during different stages of seed development (1.15 \& 1.18-folds) under E1 \& E2, respectively); so also, with increase in PHR periods (1.04 to 1.07-folds) (Fig 6).

Likewise, the total oil content in developing seed increased, under E1 (35-45 DFP) from 24.65 to $29.87 \%$; and under E2 (45-60 DFP) from 28.59 to $30.11 \%$; indicated a close proximity $(\mathrm{r}=0.99, \mathrm{p}<0.05)$ between oil content and seed developmental stages. Similarly, oil content in seed during PHR increased (1.02 to 1.04-folds), irrespective of treatments (Fig 6). One may obtain better seed quality and yield (viz TSS, TSP, total starch and oil contents) by harvesting the fruits either on 45 DFP+20-days PHR (F3P3) or 40 DFP+30-days PHR (F2P4) under open field, whereas on 55 DFP+20-days PHR (C3P3) or 50 DFP+30-days PHR (C2P4) under protected environments.

\section{ROS and antioxidants activities}

Alike seed composition, the variations for ROS $\left(\mathrm{O}_{2}{ }^{-} \& \mathrm{H}_{2} \mathrm{O}_{2}\right)$ and antioxidants (SOD, CAT \& POX), were significant between two growing environments only, irrespective of varieties and seasons. The ROS and antioxidants, under E1 \& E2 decreased significantly with the progression of seed maturation (Fig 7). The PHR seeds registered, in general, the low ROS activity, irrespective of the treatments. 30-days PHR seeds, registered a decrease in $\mathrm{H}_{2} \mathrm{O}_{2}$ activity (-1.09folds, -1.08 -folds and -1.07-folds) from harvested fruits on 35, 40 and 45 DFP, respectively under E1, whereas it decreased (1.06-folds, -1.07-folds \& -1.07-folds) from fruits harvested on 45, 50 and 55 DFP, respectively under E2 (Fig 7). A similar trend with decreased super oxide anion $\left(\mathrm{O}_{2}{ }^{\circ}\right)$ activity (-1.10-folds, -1.08 -folds \& -1.11 folds) with 30-days PHR seeds from fruits harvested on 35, 40 and 45 DFP, respectively under E1, whereas it decreased (-1.08-folds, 1.08 -folds \& -1.12 -folds) from fruits harvested on 45, 50 and 55 DFP, respectively under E2 (Fig 7). Under both the environments, the regression analysis, showed a strong but negative correlation $(\mathrm{r}=-0.97$ to $-0.99, \mathrm{p}<0.05)$ between ROS $\left(\mathrm{O}_{2}{ }^{*} \& \mathrm{H}_{2} \mathrm{O}_{2}\right)$ activity and PHR seeds harvested at different stages of development (Fig 7).

In general, the antioxidants decreased significantly with progression of seed maturity and/or increase in PHR periods. Antioxidants (SOD, CAT \& POX) from freshly harvested seeds with 0-day PHR, recorded a decrease (-1.14 \&-1.15-folds; $1.15 \&$-1.17-folds; $-1.11 \&-1.27$-folds) under E1 (35-45 DFP) \& E2 (45-55 DFP), respectively (Fig 8). 30-days PHR seeds, 
harvested at different developmental stages, recorded a decrease (-1.05 \& -1.07-folds; $1.12 \&-1.20$-folds; $-1.10 \&-1.18$-folds) under E1 \& E2, respectively. Regression analysis showed a strong but negative correlation $[\mathrm{r}=-0.97$ to $-0.99(\mathrm{p}<0.05)]$ with PHR periods (Fig 8).

Table.1 Details on various PHR period treatments and its codes

\begin{tabular}{|l|l|l|l|}
\hline \multicolumn{2}{|c|}{ E1: Open field environment } & \multicolumn{2}{c|}{ E2: Protected environment } \\
\hline Code & Harveststage + PHR & Code & Harvest stage + PHR \\
\hline F1P1 & 35-DFP+00-day & C1P1 & 45-DFP+00-day \\
\hline F1P2 & 35-DFP+10-days & C1P2 & 45-DFP+10-days \\
\hline F1P3 & 35-DFP+20-days & C1P3 & 45-DFP+20-days \\
\hline F1P4 & 35-DFP+30-days & C1P4 & 45-DFP+30-days \\
\hline F2P1 & 40-DFP+00-day & C2P1 & 50-DFP+00-day \\
\hline F2P2 & 40-DFP+10-days & C2P2 & 50-DFP+10-days \\
\hline F2P3 & 40-DFP+20-days & C2P3 & 50-DFP+20-days \\
\hline F2P4 & 40-DFP+30-days & C2P4 & 50-DFP+30-days \\
\hline F3P1 & 45-DFP+00-day & C3P1 & 55-DFP+00-day \\
\hline F3P2 & 45-DFP+10-days & C3P2 & 55-DFP+10-days \\
\hline F3P3 & 45-DFP+20-days & C3P3 & 55-DFP+20-days \\
\hline F3P4 & 45-DFP+30-days & C3P4 & 55-DFP+30-days \\
\hline
\end{tabular}

Fig.1 Effects of fruit harvest stages and post-harvest ripening periods on seed number and 1000seed weight across cucumber varieties, seasons and environments

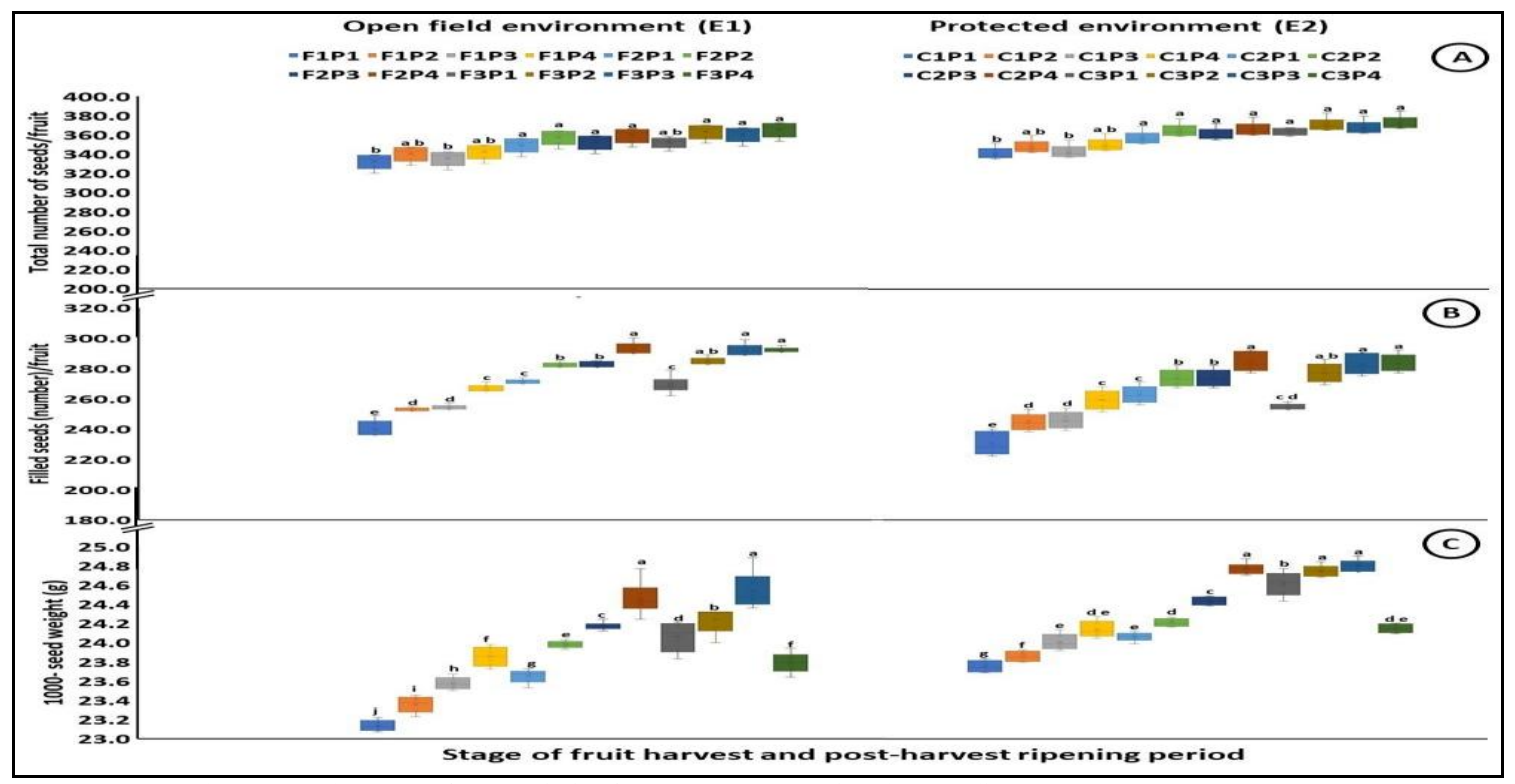

(Data represent the mean values $\pm \mathrm{SE}$ of two varieties from two seasons using three replicates;

Values denoted by different letters are significantly different at $\mathrm{p} \leq 0.05$ following Duncan's multiple range test)

[Where, (A): Total number of seeds per fruit; (B): Number of filled seed per fruit and (C): 1000-seed weight

F1, F2 and F3 are harvesting stage of fruit under open field environment at 35, 40 and 45 DFP, respectively; whereas C1, C2 and C3 are harvesting stage of fruit under protected environment at 45, 50 and 55 DFP, respectively. P1, P2, P3 and P4 denotes the post-harvest ripening period ie 0,1020 and 30-days, respectively] 
Fig.2 Effects of fruit harvest stages and post-harvest ripening period on seed dimensions across cucumber varieties, seasons and environments

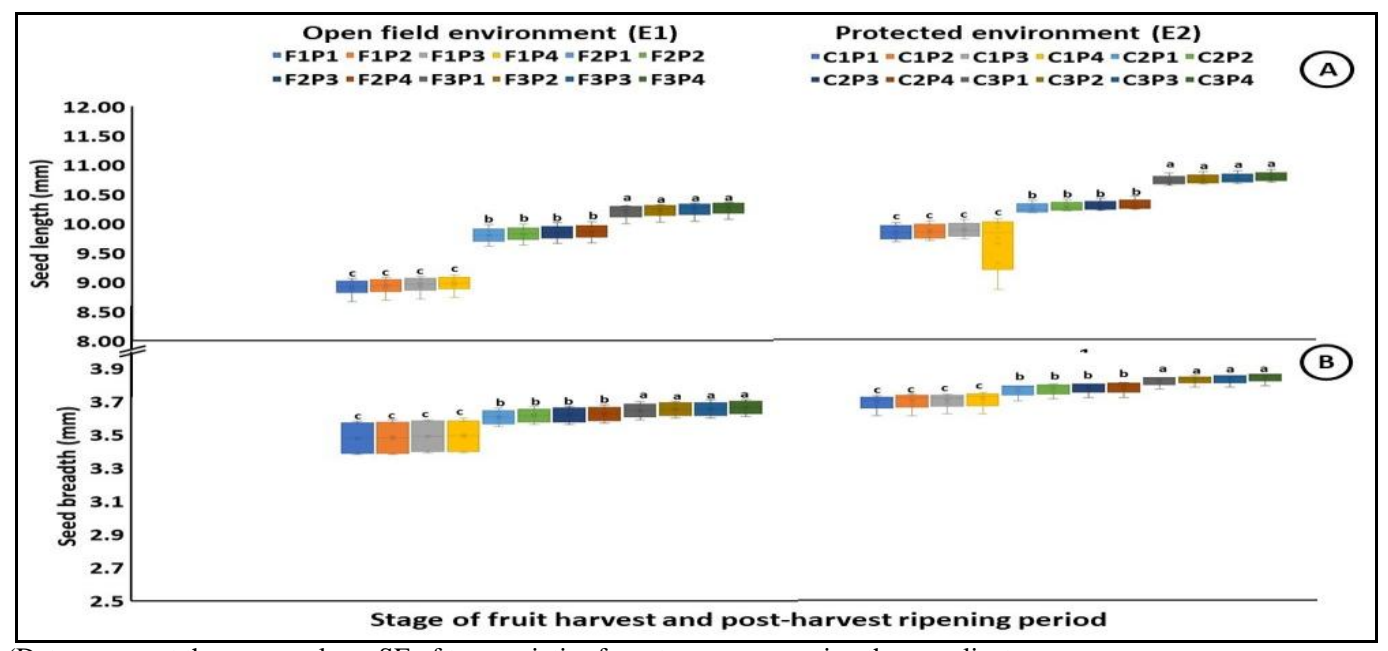

(Data represent the mean values $\pm \mathrm{SE}$ of two varieties from two seasons using three replicates;

Values denoted by different letters are significantly different at $\mathrm{p} \leq 0.05$ following Duncan's multiple range test).

[Where, (A):Seed length and (B): Seed breadth;

F1, F2 and F3 are harvesting stage of fruits under open field environment at 35, 40 and 45 DFP, respectively; whereas C1, C2 and C3 are harvesting stage of fruits under protected environment at 45, 50 and 55 DFP, respectively. P1, P2, P3 and P4 denotes the postharvest ripening period ie 0,1020 and 30-days, respectively]

Fig.3 Effects of fruit harvest stages and post-harvest ripening period on seed quality across cucumber varieties, seasons and environments

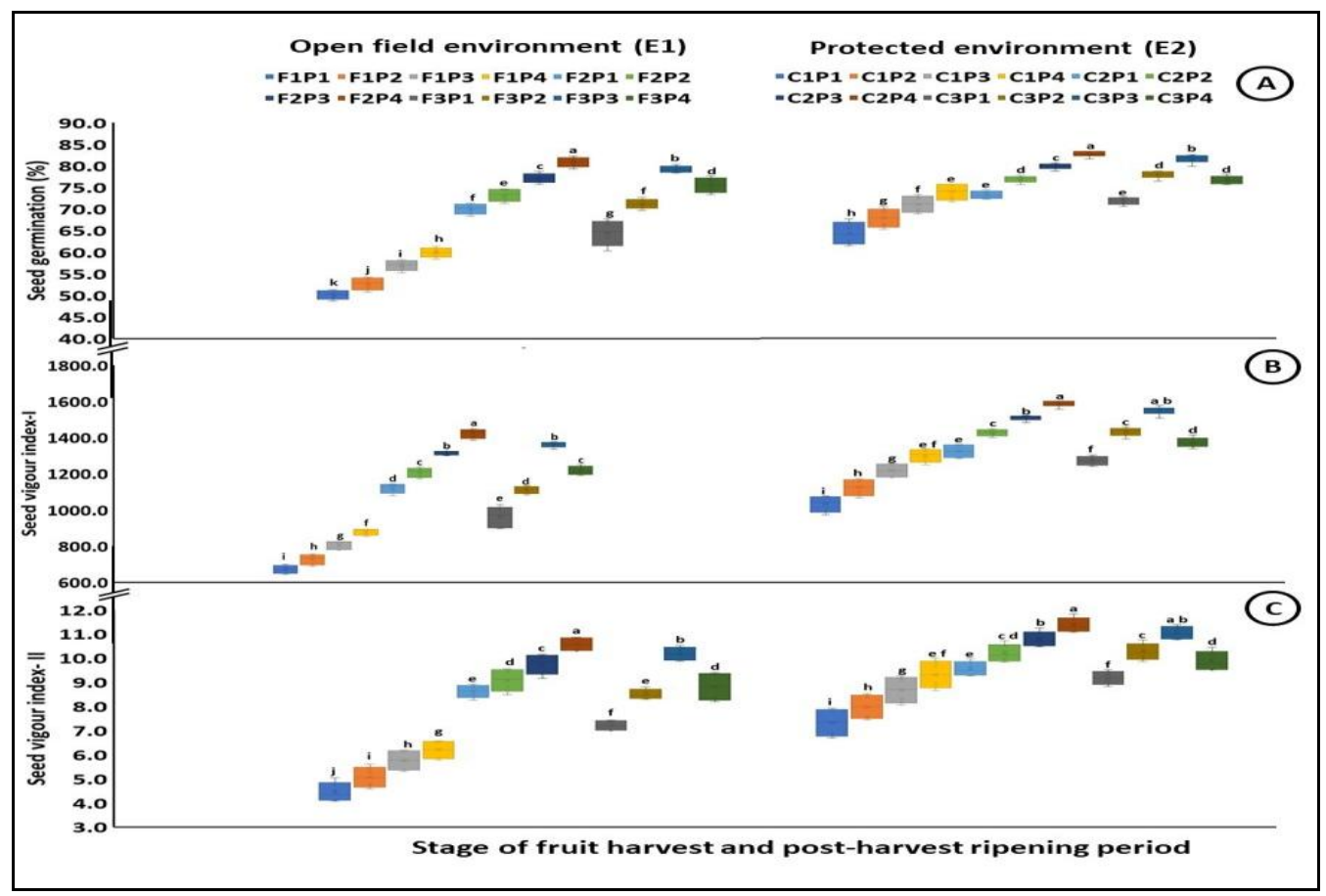

(Data represent the mean values $\pm \mathrm{SE}$ of two varieties from two seasons using three replicates;

Values denoted by different letters are significantly different at $\mathrm{p} \leq 0.05$ following Duncan's multiple range test).

[Where, (A): Seed germination percentage; (B): Seed vigour index- I; and (C):Seedvigour index-II;

F1, F2 and F3 are harvesting stage of fruit under open field environment at 35, 40 and 45 DFP, respectively; whereas C1, C2 and $\mathrm{C} 3$ are harvesting stage of fruit under protected environment at 45, 50 and 55 DFP, respectively. P1, P2, P3 and P4 denotes the post-harvest ripening period ie 0,1020 and 30 -days, respectively) 
Fig.4 Effects of fruit harvest stages and post-harvest ripening period on seed moisture content, seed fresh and dry weights across cucumber varieties, seasons and environments

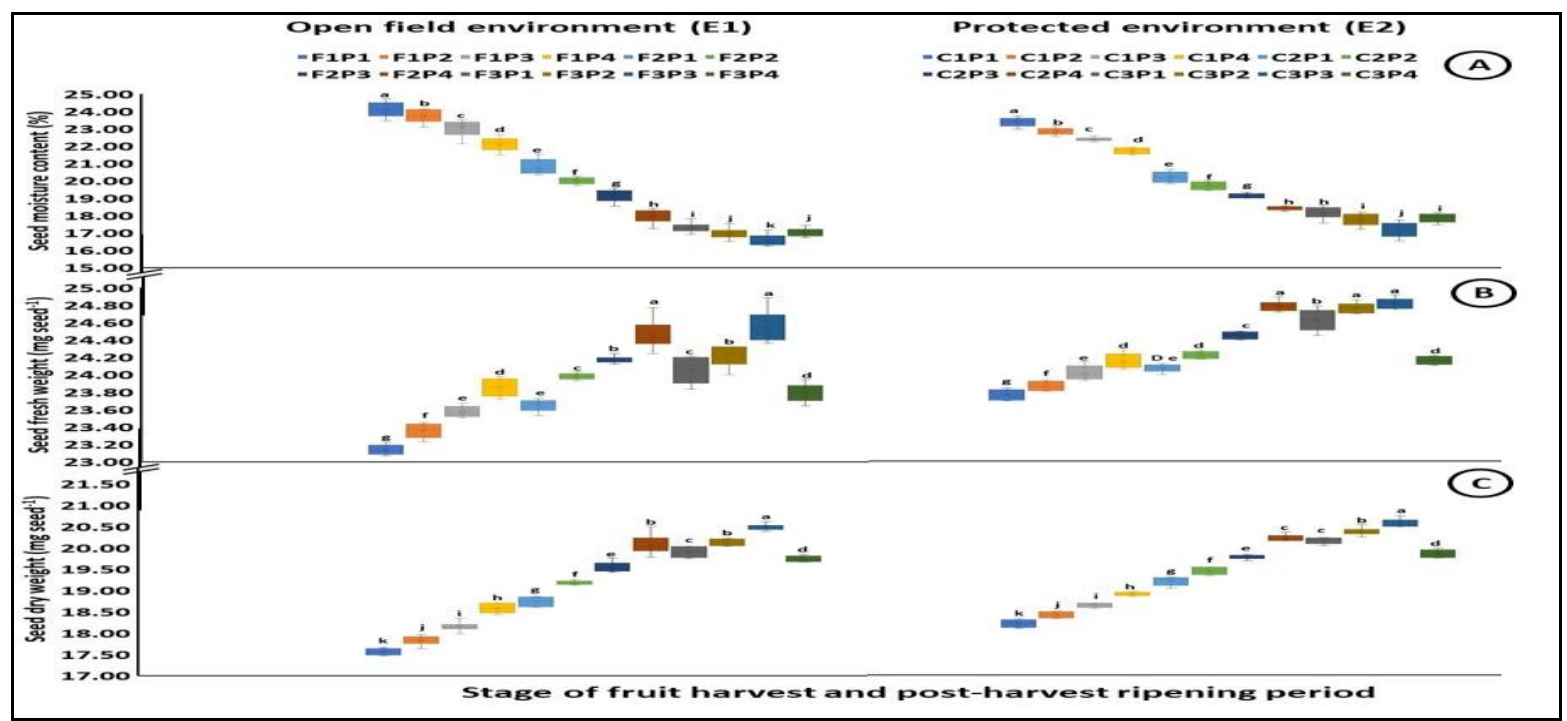

(Data represent the mean values $\pm \mathrm{SE}$ of two varieties from two seasons using three replicates;

Values denoted by different letters are significantly different at $p \leq 0.05$ following Duncan's multiple range test). [Where, (A): Seed moisture content; (B): Seed fresh weight and (C):Seed dry weight;

F1, F2 and F3 are harvesting stage of fruit under open field environment at 35, 40 and 45 DFP, respectively; whereas $\mathrm{C} 1, \mathrm{C} 2$ and $\mathrm{C} 3$ are harvesting stage of fruit under protected environment at 45, 50 and 55 DFP, respectively. P1, P2, P3 and P4 denotes the post-harvest ripening period ie 0, 1020 and 30-days, respectively)

Fig.5 Effects of fruit harvest stages and post-harvest ripening period on electrical conductance, total soluble sugars and total soluble proteins from seed leachates across cucumber varieties, seasons and environments

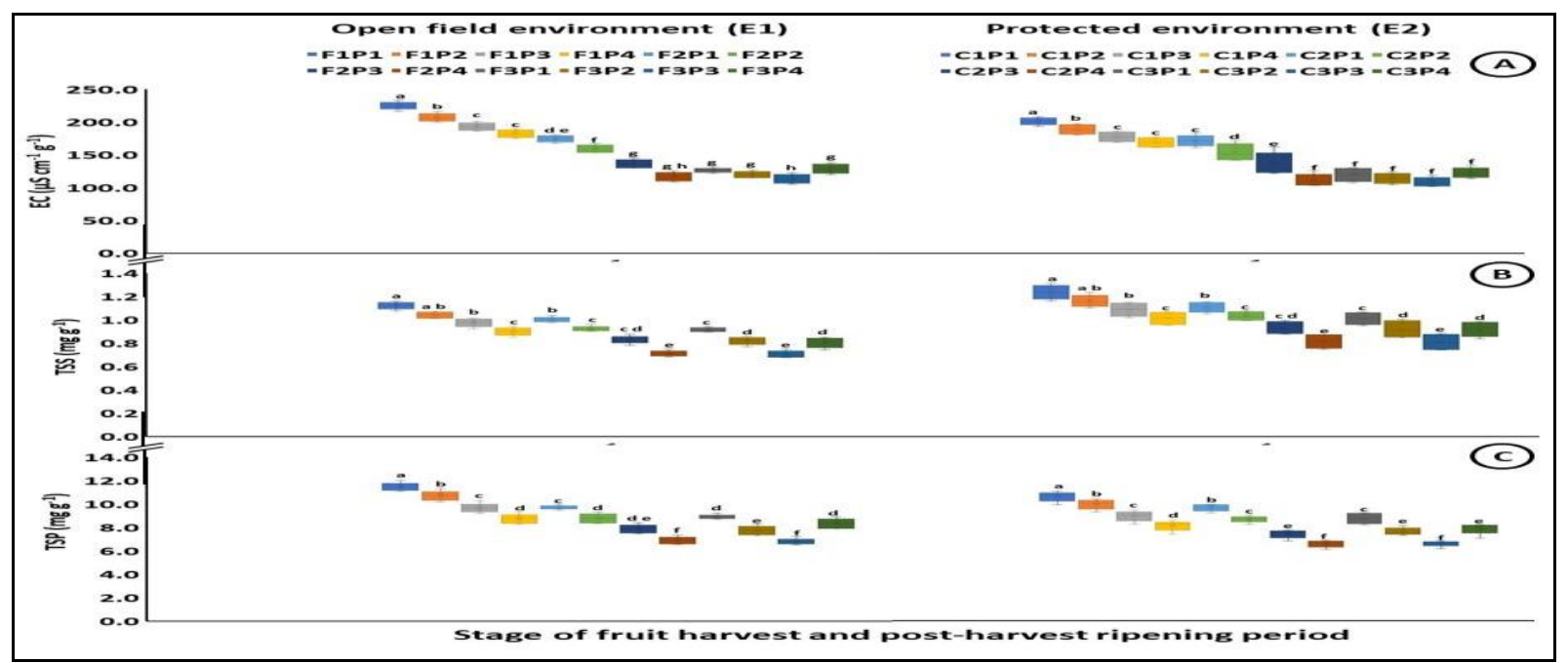

(Data represent the mean values $\pm \mathrm{SE}$ of two varieties from two seasons using three replicates;

Values denoted by different letters are significantly different at $\mathrm{p} \leq 0.05$ following Duncan's multiple range test). [Where, (A): Electrical conductance; (B): Total soluble sugars; and (C):Total soluble proteins from seed leachates; F1, F2 and F3 are harvesting stage of fruit under open field environment at 35, 40 and 45 DFP, respectively; whereas $\mathrm{C} 1, \mathrm{C} 2$ and $\mathrm{C} 3$ are harvesting stage of fruit under protected environment at 45, 50 and 55 DFP, respectively. P1, P2, P3 and P4 denotes the post-harvest ripening period ie 0, 1020 and 30-days, respectively] 
Fig.6 Effects of fruit harvest stages and post-harvest ripening period on seed composition across cucumber varieties, seasons and environments

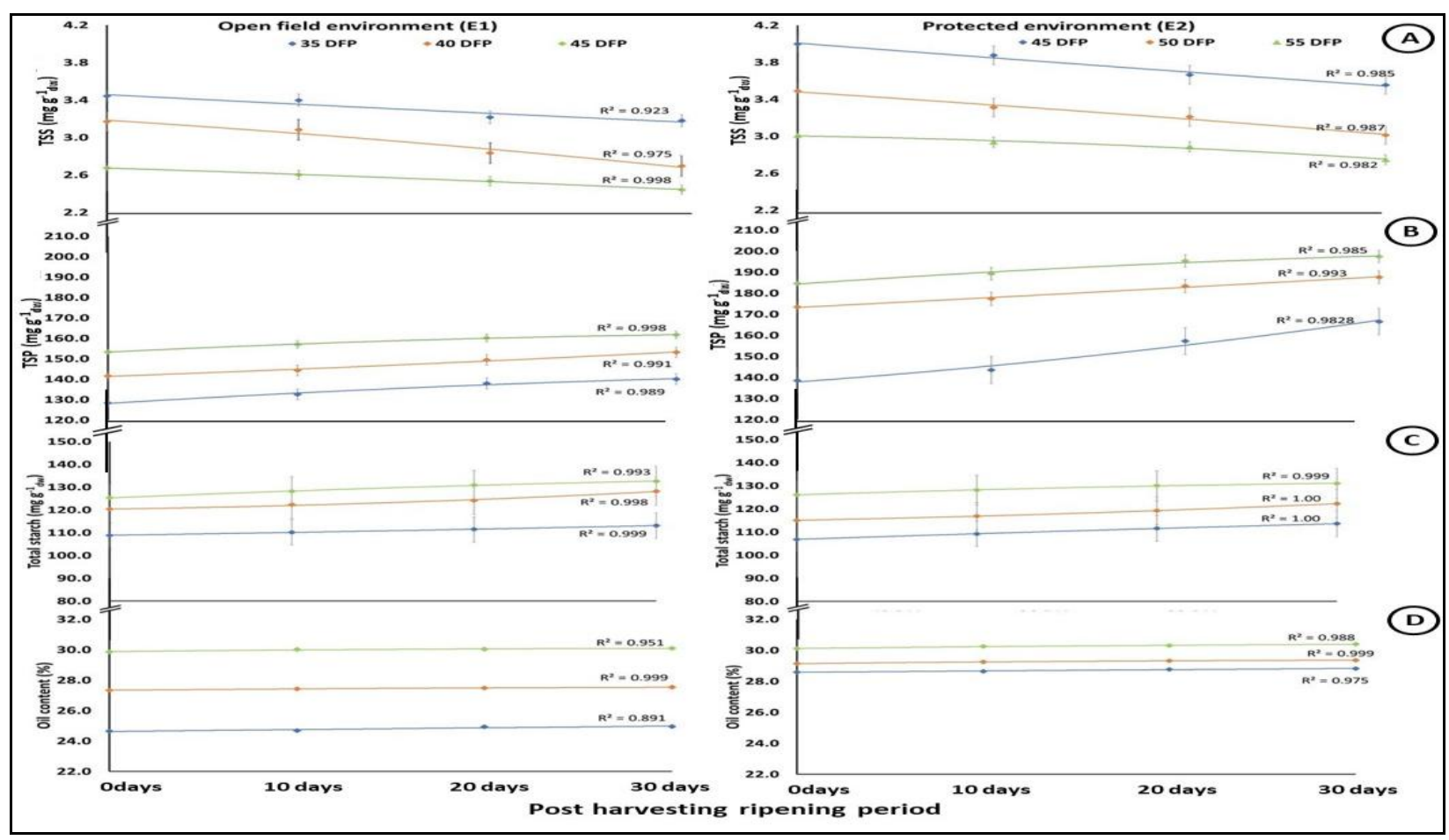

(Data represent the mean values $\pm \mathrm{SE}$ of two varieties from two seasons using three replicates;

Values denoted by different letters are significantly different at $\mathrm{p} \leq 0.05$ following Duncan's multiple range test). [Where, from seeds, (A): Total soluble sugars; (B): Total soluble proteins; (C):Total starch content; and (D) Oil content]

Fig.7 Effects of fruit harvest stages and post-harvest ripening period on ROS activity across cucumber varieties, seasons and environments

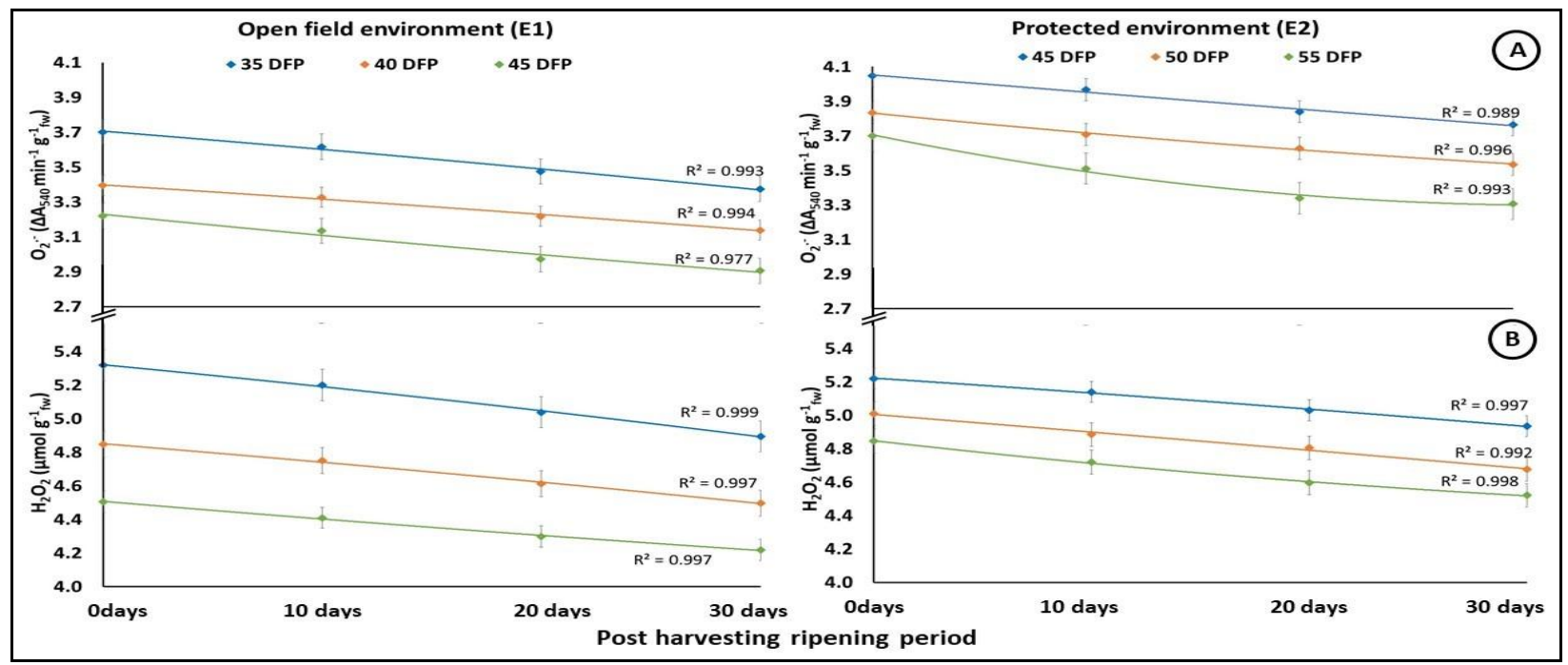

(Data represent the mean values $\pm \mathrm{SE}$ of two varieties from two seasons using three replicates;

Values denoted by different letters are significantly different at $\mathrm{p} \leq 0.05$ following Duncan's multiple range test). Where, (A): Super oxide anion $\left(\mathrm{O}_{2}{ }^{\circ}\right)$ and (B): Hydrogen peroxide $\left(\mathrm{H}_{2} \mathrm{O}_{2}\right)$ 
Fig.8 Effects of fruit harvest stages and post-harvest ripening period on antioxidants activity across cucumber varieties, seasons and environments

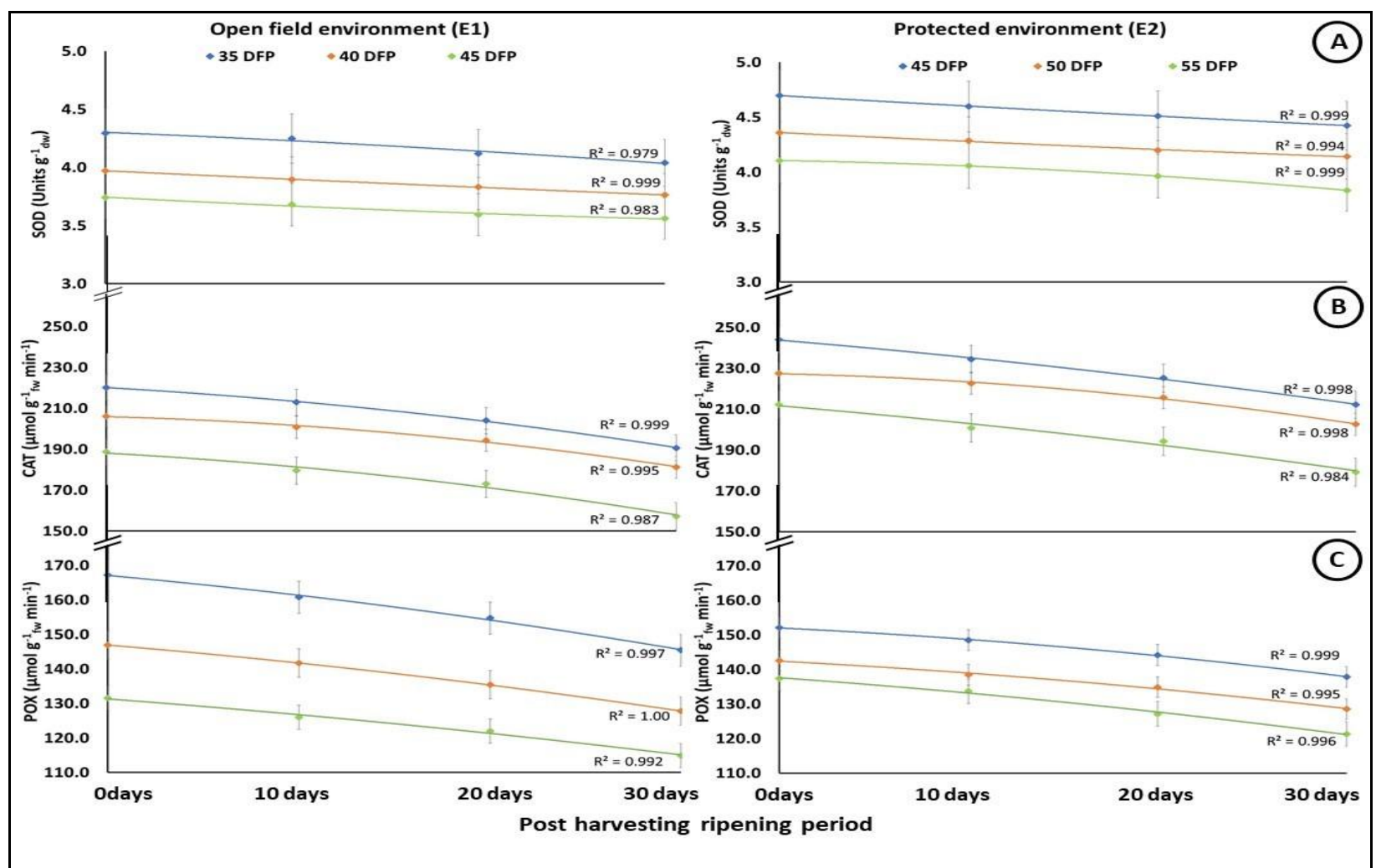

(Data represent the mean values \pm SE of two varieties from two seasons using three replicates;

Values denoted by different letters are significantly different at $\mathrm{p} \leq 0.05$ following Duncan's multiple range test). Where, (A): Super oxidedismutase (SOD); (B): Catalase (CAT); and (C) Peroxidase (POX)

\section{Seed yield}

Stages of fruit harvest in combination with post-harvest ripening period significantly affected the seed development and yield attributes. Increase in seed yield viz 1000-seed weight, seed fresh and dry weights may be due to seed as sink keep on receiving the accumulates with the advancement of seed maturity during seed development and/or post-harvest ripening period (within a fruit) (Gupta et al., 2021b). However, an increase in filled seeds per fruit during PHR indicated the reshuffling of accumulates towards under developed seeds. Seed composition registered the significant increase in total starch, TSP and oil contents, whereas TSS decreased with the advancement of seed development or maturity. The present results also registered the increase in total starch and TSP, whereas a decrease in TSS was registered; on the contrary, the total oil contents remains unaffected during PHR. Vinod $\mathrm{K}$ et al., (2014), in pumpkin, reported an increase in seed proteins and carbohydrates along with oil contents during PHR in line of my results. The increase in the total proteins, even after harvest, may be due to the continuation of metabolic processes (ie inter-conversion of free amino acids) within the plant cells. Additionally, the reduced activity of the hydrolytic enzymes (proteases and amylases) helps the fruit and in turn seeds, in accumulating the proteins and starch during the later stages of ripening (Stanley, 1998). Increase in accumulates during PHR may be 
due to transfer of assimilates from pulpy fruit to seeds.

\section{Seed quality}

Irrespective of varieties, seasons and environment, the better seed quality and yield (viz seed germination, seed vigour indices, total number of seeds per fruit, total number of filled seeds per fruit, 1000-seed weight, fresh and dry weights) increased with the advancement of developmental stages and increment in PHR period either individually or in combination. Seed composition changes may be attributed to the development of bolder seeds, which directly or indirectly attributed to the increase in seed quality ( $v i z$ seed germination and vigour) during PHR. Significant differences were registered in seeds of different harvests, for seed germination and vigour, if the fruits were subjected to various PHR periods. The present results showed an increase in seed germination and vigour in PHR-seeds, from fruits harvested at different developmental stages of both the cucumber varieties from both growing environments [ie with treatment F2P4 (40 DFP+30-days PHR) followed by F3P3 (45 DFP+20-days PHR) under E1; and with C2P4 (50 DFP+30-days PHR) followed by C3P3 (55 DFP+20-days PHR) under E2. Previous workers, on similar line of enhanced seed quality with PHR, had reported in pumpkin (Vinod K et al., 2014); hybrid pumpkin (Silva et al., 2017); water melon (Nerson, 2002); Indian chilli (Pandita and Nagarajan, 2001); pepper (Oladiran and Kortse, 2002); tomato (Dias et al., 2006) and french bean (Shaheb et al., 2015). Improved vigour in PHR-seeds may also be attributed to better seed longevity or storability (Alan and Eser, 2008; Passam et al., 2010).

One of the possible reasons for increased germination in PHR-seeds over freshly harvested seeds could be the breakdown of dormancy. Seed dormancy may be due to the accumulation of some germination inhibitors, which were depleted as seed storage progressed. It may be due to either presence of or the sensitivity of abscisic acid in seeds, which was also reduced with PHR periods (Finch-savage and Leubner-metzger, 2006). Besides, the role of ROS and antioxidants were expected in regulation of seed dormancy. Second possibility of the higher germination in PHR-seeds may be attributed to the increased growth potential of the embryo, and cell wall degradation enzymes during storage, which enhanced the capability of radicle to penetrate surrounding physical barrier in seeds (Iglesias-fernandez and Matilla, 2009). Third possibility of higher seed quality in PHR-seeds may be attributed to the greater accumulation of food reserves in seeds such as tomato (Hamsaveni et al., 2003) and chili (Pandita and Nagarajan, 2001). Fourth possibility of improved germination in eight months after-ripening seeds might be due to development of mature embryos and acquisition of desiccation tolerance (Murugesan and Vanangamudi, 2005). The present results need validation. Besides, PHR of fruits allow an early harvest of crop; resulting in prevention from various biotic and abiotic stresses. In another possibility, Iglesias-fernandez and Matilla (2009), in seeds of Sisymbrium officinale L, reported that after-ripening: (i) alters the gene expression pattern of several functional genes including oxidases which was involved in the ethylene and gibberellins pathways during early imbibitions, as both of these hormones are positively involved in germination; (ii) quantitatively increased the rate of initial water uptake, which support rapid germination. Whereas, Carrera et al., (2008) reported that ABA sensitivity (germination inhibitor and dormancy promoter) was reduced during after-ripening in Arabidopsis. Thus, it may be inferred that PHR in cucumber be opted as a dormancy breaking 
treatment; various physiological and biochemical events related to release of dormancy and germination improvement occurs during PHR period.

Seed germination and vigour increased up to 40 \& 50 DFP under E1 \& E2, respectively, this period, a possible indication of seed physiological maturity, have maximal seed germinability. Whereas, seed dry weight at PM was not at peak, as seed filling continued up to fruit harvesting and/or even after fruit harvesting with PHR. Further after PM, seed viability and vigour slightly decreased, may be attributed to inactivation of certain enzymes or reduced cell membrane integrity.

\section{Physiological and biochemical attributes of seed quality}

The moisture contents in fruits and seeds decreased gradually with advancement of maturity and PHR, may be due to the natural disintegration of fruit and evaporation of water, resulted a decrease in fruit weights. The changes in fruit dimension during PHR period, may be due to the loss of moisture, which was non-significant. Similar results of loss in seed moisture with increased PHR period were reported in chilli (Pandita and Nagarajan, 2001); in pepper (Alan and Eser, 2008); in bottle gourd (Kalyanrao et al., 2014). During the PHR period, fruit weight loss resulted in dehydration of fruits leaving pithy pulp and seed mass intact (Murugesan and Vanangamudi, 2005). The increase in seed dry weight during PHR may be attributed to continued supply of accumulates and nutrients from stored fruits. The results were in confirmation with work of Passam et al., (2010) in eggplant and Kalayanrao et al., (2014) in bottle gourd. On contrary, Alan and Eser (2008) reported the decline in seed weight of pepper during PHR; seed tend to respire and use the food reserves (Carvalho and Nakagawa, 2000). However, Sanchez et al (1993) reported a non-significant change in seed dry matter in bell-pepper during PHR.

Electrical conductance from the seed leachates significantly reduced with advancement in harvesting stages and PHR periods under both the environments, which was positively correlated with TSS and TSP (in seed leachates). A decrease in seed moisture and EC, in general, during PHR indicated the physiological soundness (vigour) of seed; exceptions with treatments F3P4 and C3P4, which may be due to the increased moisture and EC with fruit rotting. Reduction of cucumber seed yield and quality due to extended period of PHR were more severe from summer season crop under open field environment than either winter season crop or protected environment crop, which could be due to the synergetic effects of high temperature, low oxygen and high $\mathrm{CO}_{2}$, low water potential, partial pressures (Edelstein $e t$ $a l$, 1995). Normally, PHR allows seeds to remain embedded in fruit pulp, with moisture content close to imbibitions and optimum available oxygen, but with prohibited germination, help to maintain their viability for significant periods, as such encouraged cellular repair for maintaining vigour and viability (Dias et al., 2006). But delay in harvest or extended PHR period may lead to reduction in seed quality and yield due to decomposition of fruits \& seeds; and precocious germination (vivipary) (Alan and Eser, 2008). In fleshy fruit such as cucumber, precocious germination of seeds within a fruit is controlled by hormonal regulation in early development stages and by the osmotic potential of the fruit in later development stages (Bradford, 2004). Delay in harvest and PHR allows fruits to rotten and decompose, a decrease sensitivity to osmotic inhibition resulted in precocious germination.

Seed maturation and post-harvest ripening period have been described as an oxidative 
process in several fruits especially in climacteric fruits (Rogiers et al., 1998). To observe the mechanisms underlying the later seed development stages and PHR in cucumber seeds, ROS and antioxidants play an vital role in seeds. Generally, the production of ROS is under strict supervision of antioxidants; decides the fate of seed viz germination, dormancy or oxidative stress caused cell death by triggering cellular events (hormone signalling), and direct oxidation of a subset of biomolecules. Besides, ROS and antioxidants play pivotal role in the regulation of seed development and maturation, seedling establishment, and seed ageing (Bailly, 2019). In present study, there were reduced ROS activities in PHR-seeds from all developmental stages, may be due to reduction in seed moisture, which imposes a lower potential threat to seed, consequently reduced antioxidants (SOD, CAT and POX) under both the growing environments. Similar works were reported by Silva et al., (2017) in pumpkin, Matamoros et al., (2009) in pea and Gupta et al., (2021c) in cucumber. On contrary, Vidigal et al., (2009) reported that the release of moisture from immature seed of capsicum during PHR cause the stress to seed, resulting in higher ROS generation and increased activity of antioxidant enzymes to scavenge the same. However, the higher antioxidants activity in freshly harvested seeds of cucumber is to scavenge the higher concentration of free radicals, due to high moisture stress and decline in antioxidants with PHR period, indicative of resistance to seed desiccation. Among antioxidants, SOD is one of the important enzymes, which dismutase the superoxide anion $\left(\mathrm{O}_{2}{ }^{-*}\right)$ and convert it into $\mathrm{H}_{2} \mathrm{O}_{2}$ and oxygen, further this $\mathrm{H}_{2} \mathrm{O}_{2}$ is detoxified by CAT and POX (Gill and Tuteja, 2010). Nevertheless, the cucumber seed contains about $30 \%$ oil, thus the role of these antioxidants become more important to reduce lipid peroxidation in seeds, especially a mention of CAT, as it removes $\mathrm{H}_{2} \mathrm{O}_{2}$ generated during $\beta$-oxidation of fatty acids (Bewley and Black, 1994). My studies, registered an overall decrease in ROS and antioxidants, during seed development and PHR. These results underline the importance of SOD, CAT and POX, as part of the antioxidants network. Similar, results were reported by Matamoros et al., (2009) in pea during seed maturation and storage of fruit.

In conclusion it may be inferred that, fruits of cucumber should be harvested on 45 DFP under open field and 60 DFP under protected environments; moreover at complete plantdry-stage or when fruit turns brown and warty. For higher seed quality, harvested fruits should be subjected to post-harvest ripening either for about 20-days, if harvested at full maturity, or for 30-days, if harvested 5days prior to full maturity. Furthermore, seed crop of cucumber for higher seed yield and quality preferably be planted under protected environments. Post-harvest-ripening period of seed not only provides an opportunity of an early harvest of fruits with better quality and yield but also provides an additional period to seed maturation (seed within the fruit showed decrease in $\mathrm{mc} \%$, EC, increase in food reserves, balanced ROS and antioxidants production during PHR), resulting in improved seed germination and vigour. These changes, in combination, indicated the physical and physiological soundness of seeds during PHR. Besides, PHR allows the immature seed to mature within a fruit and prevent the damages by drying (cell membrane integrity) leading to reduced generation of ROS and consequently, reduced antioxidants.

\section{References}

Abdul-baki AA and Anderson JD (1973) Vigour determination in soybean by multiple criteria Crop Science 13: 63037. 
Aebi H (1984) Catalase In vitro Methods in Enzymology 105: 121-26.

Alan O and Eser B (2008) The effect of fruit maturity and post-harvest ripening on seed quality in hot and conic pepper cultivars Seed Science and Technology 36: 467-74.

Anonymous (2019) International Rules for Seed Testing International Seed Testing Association-8303 Barsserssorf, $\mathrm{CH}-$ Switzerland pp 5-21, 9-4, 12-1

AOAC (1990) Official Methods of Analysis (15 ${ }^{\text {th }}$ edn) Methods 932.06, 925.09, 985.29, 923.03 Association of Official Agricultural Chemists Washington DC

Bailly C (2019) The signalling role of ROS in the regulation of seed germination and dormancy. Biochemical Journal 476(20): 3019-32

Bewley JD and Black M (1994) Seeds: Physiology of Development and Germination ( $2^{\text {nd }}$ edn) Plenum Press, New York, USA pp 445

Bradford KJ (2004) Seed production and quality College of Agricultural \& Environmental Sciences http://veghome.ucdavis.edu pp 31-57

Bradford MM (1976) A rapid and sensitive method for the quantitation of microgram quantities of protein utilizing the principle of protein-dye binding Analytical Biochemistry 72: 248-54

Carrera E, Holman T, Medhurst A, Dietrich D, Footitt S, Theodoulou FL and Holdsworth MJ (2008) Seed afterripening is a discrete developmental pathway associated with specific gene networks in Arabidopsis. The Plant Journal 53: 214-24.

Carvalho NM and Nakagawa J (2000) Seeds: Science, Technology and Production ( $4^{\text {th }}$ edn) Jaboticabal FUNEP 5 pp 588

Chaltanya KSK and Naithani SC (1994) Role of superoxide, lipid peroxidation and superoxide dismutase in membrane perturbation during loss of viability in seeds of Shorearobusta Gaertn F New Phytology 126: 623-27.

Delouche JC (1980) Environmental effects on seed development and seed quality HortScience 15: 775-80.

Dhindsa RS, Plumb-dhindsa P and Thorpe TA (1981) Leaf senescence: Correlated with increased levels of membrane permeability and lipid peroxidation, and increased levels of superoxide dismutase and catalase Journal of Experimental Botany 32: 93-101

Dias DCFS, Ribeiro FP, Dias LAS, Silva DJH and Vidigal DS (2006) Tomato seed quality in relation to fruit maturation and post-harvest storage Seed Science and Technology 34(3): 691-99

Dubois M, Gilles K, Hamilton J, Rebes P and Smith F (1956) Colorimetric method determination of sugars and related substance Analytical Biochemistry 28: 350-56.

Edelstein M, Corbineau F, Kigel J and Nerson $H$ (1995) Seed coat structure and oxygen availability control low temperature germination of melon (Cucumis melo) seeds Physiologia Plantarum 93: 451-56.

Finch-savage WE and Leubner-metzger G (2006) Seed dormancy and the control of germination New Phytologist 171: 501-23.

Gill SS and Tuteja N (2010) Reactive oxygen species and antioxidant machinery in abiotic stress tolerance in crop plants Plant Physiology and Biochemistry 48: 909-30

Gupta N, Jain SK and Tomar BS (2021a) Physio-biochemical changes associated with spatial differences of ovules in cucumber (Cucumis sativus L) fruit under open field and protected environments. Vegetable Science (accepted)

Gupta N, Jain SK, Tomar BS, Anand A, 
Singh J and Singh AK (2021b) Morphophysiological and biochemical changes during seed development in cucumber (Cucumis sativus $\mathrm{L}$ ) under protected and open field environments. Indian Journal of Agricultural Sciences (accepted)

Gupta N, Jain SK, Tomar BS, Anand A, Singh J and Singh AK (2021c) Physiological and biochemical changes associated with fruit load per vine and seed quality in cucumber (Cucumis sativus L) under open field and protected environments. Indian Journal of Horticulture (accepted)

Hamsaveni MR, Kurdikeri MB, Shekargouda M, Shashidhara SD and Dharmatti PR (2003) Influence of harvesting stages and post-harvest ripening periods on seed quality in tomato (cv Megha) Karnataka Journal of Agriculture Science 16: 597-99

Harrington JF (1972) Seed storage and longevity In: TT Kozlowski (ed) Seed Biology Vol III Academic Press New York, USA pp 145-45

Hodge JE and Hofreiter BT (1962) Determination of reducing sugars and carbohydrates In:RLWhistler and ML Wolfram (eds) Methods in Carbohydrate Chemistry Vol I Academic Press New York \& London pp 380-94

Iglesias-fernandez R and Matilla A (2009) After-ripening alters the gene expression pattern of oxidases involved in the ethylene and gibberellin pathways during early imbibition of Sisymbrium officinale L seeds Journal of Experimental Botany 60(6): 1645-61 DOI:10.1093/jxb/erp029

Jing HC, Bergervoet JHW, Jalink H, Klooster M, Du SL, Bino RJ, Hilhorst HWM and Groot SPC (2000) Cucumber (Cucumis sativus L) seed performance as influenced by ovary and ovule position Seed Science Research 10: 435-45
Kalyanrao, Tomar BS and Singh B (2014) Effect of stage of harvest and postharvest ripening on hybrid seed yield and quality in bottle gourd Indian Journal of Horticulture 71(3): 428-32

Katinas L, Hernandez MP, Arambarri AM and Funk VA (2016) The origin of the bifurcating style in Asteraceae (Compositae) Annals of Botany 117: 1009-21

Kortse PA, Oketa A and Apaa F (2017) Effects of stage or fruit harvesting and after-ripening on the seed quality of garden egg (Solanum melongena L) IOSR Journal of Agriculture and Veterinary Science 10(9): 10-4

Matamoros MA, Loscos J, Dietz KJ, Aparicio-tejo PM and Becana M (2009) Function of antioxidant enzymes and metabolites during maturation of pea fruits Journal of Experimental Botany 61(1): 87-97 DOI:10.1093/jxb/erp285

Mukherjee SP and Choudhari MA (1983) Implications of water stressed induced changes in the levels of endogenous ascorbic acid and hydrogen peroxide in Vigna seedlings Physiologia Plantarum 58: $166-70$

Murugesan P and Vanangamudi K (2005) Effect of post-harvest fruit storage on seed quality in ash gourd (Benincasahispida (Thvnb) Cogn) Seed Research 33(2): 160-64

Nerson H (2002) Effects of seed maturity, extraction practices and storage duration on germinability on watermelon Scientia Horticulturae 93: 245-56

Oladiran JA and Kortse PA (2002) Variations in germination and longevity of pepper (Capsicum annum $\mathrm{L}$ ) seed harvested at different stages of maturation Acta Agronomica Hungarica50(2): 157-62

Pandita VK and Nagarajan S (2001) Fruit maturity and post-harvest ripening affecting chilli seed quality and field emergence Seed Research 29(1): 21-23 
Pandita VK and Nagarajan S (2006) Role of sugars and proteins in development of desiccation tolerance in fresh and shadedried onion seeds Australian Journal of Experimental Agriculture 46: 1225-30

Passam HC, Theodoropoulou S, Karanissa T and Karapanos IC (2010) Influence of harvest time and after-ripening on the seed quality of eggplant Scientia Horticulturae 125(3): 518-20

Rao MV, Paliyathm G and Ormond DP (1996) Ultraviolet-B and ozone induced biochemical changes in antioxidant enzymes in Arabidopsis thaliana Plant Physiology 110: 125-36

Rogiers SY, Kumar GM and Knowles NR (1998) Regulation of ethylene production and ripening by saskatoon (Amelanchier alnifolia Nutt) fruit Canadian Journal of Botany 76(10): 1743-54

Sanchez VM, Sundstrom FJ, McClure GN and Lang NS (1993) Fruit maturity, storage and postharvest maturation treatments affect bell pepper (Capsicum annuит L) seed quality Scientia Horticulturae 54(3): 191-201
Shaheb MR, Islam MN, Nessa A and Hossain MA (2015) Effect of harvest times on the yield and seed quality of french bean Research Journal of Agriculture and Forestry Sciences 13(1): 1-13

Silva PP, Barros ACSA, Dias DCFS, Sekita MC and Nascimento WM (2017) Biochemical changes in hybrid pumpkin seeds at different stages of maturation Revista Ciência Agronômica. 48(3): 558-64.

Stanley JK (1998) Post-harvest Physiology of Perishable Plant Products $C B S$ Publishers and Distributors New Delhi pp 143-256

Vidigal DDS, Dias DCFS, Pinho EVDRV and Dias LADS (2009) Alteraçõ esfisiológicas e enzimáticas durante a maturação de sementes de pimenta (Capsicum annuum L) RevistaBrasileira de Sementes31(2): 129-36

Vinod K, Tomar BS, Singh B and Sanjay K (2014) Effect of stage of harvest and post-harvest ripening of fruits on hybrid seed yield and quality in pumpkin (Cucurbita moschata) Indian Journal of Agricultural Science 84(6): 737-41.

\section{How to cite this article:}

Nakul Gupta, Sunil Kumar, S. K. Jain, B. S. Tomar, Jogendra Singh and Vishwanath Sharma. 2021. Effects of Stage of Harvest and Post-harvest Ripening of Fruits on Seed Yield and Quality in Cucumber Grown under Open Field and Protected Environments. Int.J.Curr.Microbiol.App.Sci. 10(01): 2119-2134. doi: https://doi.org/10.20546/ijcmas.2021.1001.244 